University of Nebraska - Lincoln

DigitalCommons@University of Nebraska - Lincoln

\title{
A one-dimensional heat-transport model for conduit flow in karst aquifers
}

Andrew J. Long

U.S. Geological Survey, ajlong@usgs.gov

Patrick C. Gilcrease

South Dakota School of Mines and Technology, Patrick.Gilcrease@sdsmt.edu

Follow this and additional works at: https://digitalcommons.unl.edu/usgsstaffpub

Part of the Earth Sciences Commons

Long, Andrew J. and Gilcrease, Patrick C., "A one-dimensional heat-transport model for conduit flow in karst aquifers" (2009). USGS Staff -- Published Research. 429.

https://digitalcommons.unl.edu/usgsstaffpub/429

This Article is brought to you for free and open access by the US Geological Survey at DigitalCommons@University of Nebraska - Lincoln. It has been accepted for inclusion in USGS Staff -- Published Research by an authorized administrator of DigitalCommons@University of Nebraska - Lincoln. 


\title{
A one-dimensional heat-transport model for conduit flow in karst aquifers
}

\author{
Andrew J. Long ${ }^{\mathrm{a}, *}$, Patrick C. Gilcrease ${ }^{\mathrm{b}}$ \\ a US Geological Survey, 1608 Mountain View Rd., Rapid City, SD 57702, United States \\ ${ }^{\mathrm{b}}$ South Dakota School of Mines and Technology, Department of Chemical and Biological Engineering, 501 East Saint Joseph Street, Rapid City, SD 57701, United States
}

\section{A R T I C L E I N F O}

\section{Article history:}

Received 9 January 2009

Received in revised form 17 July 2009

Accepted 11 September 2009

This manuscript was handled by P. Baveye, Editor-in-Chief, with the assistance of Michel Bakalowicz, Associate Editor

\section{Keywords:}

Heat transport

Karst

Modeling

Groundwater

\begin{abstract}
S U M M A R Y
A one-dimensional heat-transport model for conduit flow in karst aquifers is presented as an alternative to two or three-dimensional distributed-parameter models, which are data intensive and require knowledge of conduit locations. This model can be applied for cases where water temperature in a well or spring receives all or part of its water from a phreatic conduit. Heat transport in the conduit is simulated by using a physically-based heat-transport equation that accounts for inflow of diffuse flow from smaller openings and fissures in the surrounding aquifer during periods of low recharge. Additional diffuse flow that is within the zone of influence of the well or spring but has not interacted with the conduit is accounted for with a binary mixing equation to proportion these different water sources. The estimation of this proportion through inverse modeling is useful for the assessment of contaminant vulnerability and well-head or spring protection. The model was applied to 7 months of continuous temperature data for a sinking stream that recharges a conduit and a pumped well open to the Madison aquifer in western South Dakota. The simulated conduit-flow fraction to the well ranged from $2 \%$ to $31 \%$ of total flow, and simulated conduit velocity ranged from 44 to $353 \mathrm{~m} / \mathrm{d}$.
\end{abstract}

Published by Elsevier B.V.

\section{Introduction}

The use of heat as a groundwater tracer, in contrast to the use of chemical tracers, is attractive because of the ease of measuring temperature with high precision (errors as low as $\pm 0.03{ }^{\circ} \mathrm{C}$ ). Groundwater temperatures are influenced by the temperature of recharge, mixing of different waters resulting from groundwater flow, and the earth's geothermal gradient. A long history of the use of heat as a groundwater tracer beginning in the 1960s is described by Anderson (2005). A few examples of the numerous heat-transfer applications in hydrology include those by Bredehoeft and Papadopulos (1965), Edinger et al. (1968), Lu and Ge (1996), Bogan et al. (2003), and Shoemaker et al. (2005). Groundwater flow and heat-transport computer codes include Voss and Provost (2002) and Healy and Ronan (1996).

Temperature fluctuations at the outlets of karst aquifers commonly are observed to range from 0.01 to several degrees Celsius (Benderitter et al., 1993). There are several examples of heat-transfer method development and applications for karst hydrology. Applications to assess cave temperatures and gaining and sinking streams include Genthon et al. (2005), O'Driscoll and DeWalle (2006), and Dogwiler et al. (2007). Groundwater applications have been developed to model quick-flow in karst pipes or conduits, diffuse flow in fissures and other small openings, and the interaction

\footnotetext{
* Corresponding author. Tel.: +1 605394 3237; fax: +1 6053554523 .

E-mail address: ajlong@usgs.gov (A.J. Long).
}

of these two flow regimes. Three-dimensional fluid flow and solute/heat-transfer models that include both of these flow regimes include Benderitter et al. (1993), Liedl and Sauter (2000), Birk (2002), Andre and Rajaram (2005), and Birk et al. (2006). With these distributed-parameter models, velocities are estimated from the flow simulation and then are used in the transport simulation. Additional insight into general heat-transfer theory for pipe and channel flow is described by Gnielinski (1976), Aravinth (2000), Beek et al. (1999), and Benim et al. (2004).

Two- or three-dimensional distributed-parameter models are data intensive and are useful when the locations of conduits are known; however, information on conduit locations usually is unavailable. For cases where wells or springs have a temperature response that is influenced by conduit flow, but the conduit network is not well defined, an alternative approach may be useful. This paper presents a one-dimensional numerical heat-transport model that is explored as an alternative that might be useful when a primary objective is to estimate the relative fractions of conduit flow and diffuse flow. This model simulates the temperature response to recharge in a well or spring and assumes that the well or spring receives at least some of its water from a nearby conduit. Transport in the conduit is simulated with a physically-based heattransport equation, and additional diffuse flow entering the well or spring is accounted for with a binary mixing equation to proportion conduit flow and diffuse flow. The conduit is assumed to be cylindrical with constant diameter and wall roughness. The model does not simulate flow of water (i.e., pressure transfer), and thus 
conduit velocity needs to be estimated through inverse modeling using measured temperature data or estimated from other tracer experiments.

The model was tested in an application to a pumped well open to the Madison aquifer in the Black Hills of western South Dakota, where the aquifer is recharged by a sinking stream that enters a conduit. The relative fractions of conduit flow and diffuse flow were estimated by using inverse modeling. These flow fractions are important parameters for assessing vulnerability to contaminants, and thus the model may have applications for well-head or spring protection for karst aquifers.

\section{The heat-transport model}

The model uses an energy balance equation for flow in a karst conduit, heat-transfer between the conduit wall and water, and inflow of diffuse flow along the length of the conduit. An energy balance for a cylindrical conduit element (Fig. 1) is written as \{Heat accumulation rate $\left(\mathrm{J} \mathrm{s}^{-1}\right)=$ flow in - flow out + convective heat from conduit wall + heat from additional inflow from the aquifer or

$$
\begin{aligned}
A \Delta x \rho C_{p} \frac{\partial T_{q}}{\partial t}= & \left.\frac{\hat{m} C_{p} T_{q}}{x}\right|_{x}-\left.\underline{\hat{m} C_{p} T_{q}}\right|_{x+\Delta x}+h_{t}(\pi D \Delta x)\left(T_{r}-T_{q}\right) \\
& +q_{s} \rho \Delta x C_{p} T_{s},
\end{aligned}
$$

where $A$ is the cross sectional area $\left(\mathrm{m}^{2}\right) ; \Delta x$ is the length of the conduit element; $x$ is the space coordinate along the conduit axis (m); $\rho$ is the density of water $\left(999.6 \mathrm{~kg} \mathrm{~m}^{-3}\right.$ at $\left.12{ }^{\circ} \mathrm{C}\right) ; C_{p}$ is the heat capacity of water $\left(4190 \mathrm{~J} \mathrm{~kg}^{-1} \mathrm{~K}^{-1}\right.$ at $\left.12^{\circ} \mathrm{C}\right) ; T_{q}$ is the temperature of the bulk water flowing in the conduit $(\mathrm{K}) ; t$ is time $(\mathrm{s}) ; \hat{m}$ is the mass flow rate of water along the conduit axis $\left(\mathrm{kg} \mathrm{s}^{-1}\right) ; h_{t}$ is the convective heat-transfer coefficient between the conduit water and conduit wall $\left(\mathrm{J} \mathrm{s}^{-1} \mathrm{~m}^{-2} \mathrm{~K}^{-1}\right)$; $D$ is the conduit diameter $(\mathrm{m})$; $T_{r}$ is the temperature of the conduit wall $(\mathrm{K})$; and $q_{s}$ and $T_{s}$ are the flow rate per unit length of conduit $\left(\mathrm{m}^{3} \mathrm{~s}^{-1} \mathrm{~m}^{-1}\right)$ and temperature $(\mathrm{K})$, respectively, of diffuse flow entering the conduit. A dispersion term was not included because flow in karst conduits generally is turbulent, which results in minimal longitudinal dispersion in a straight conduit. If the altitude of the conduit changes along its length, $T_{r}$ and $T_{s}$ at different depths are affected by the geothermal gradient but are assumed constant in time. This is only an approximation because changes in the temperature of conduit water may affect the rock temperature to some degree. Parameters $\rho, D$, and $C_{p}$ are assumed constant.

Dividing Eq. (1) by $A \Delta x \rho C_{p}$ results in

$\frac{\partial T_{q}}{\partial t}=-\frac{1}{A \rho} \frac{\left(\left.\underline{\hat{m} T_{q}}\right|_{x+\Delta x}-\left.\underline{\hat{m} T_{q}}\right|_{x}\right)}{\Delta x}+\frac{h_{t} \pi D}{A \rho C_{p}}\left(T_{r}-T_{q}\right)+\frac{q_{s}}{A} T_{s}$,

which simplifies to the following equation as $\Delta x \rightarrow 0$ :

$\frac{\partial T_{q}}{\partial t}=\frac{h_{t} \pi D}{A \rho C_{p}}\left(T_{r}-T_{q}\right)-\frac{1}{A \rho} \frac{\partial\left(\hat{m} T_{q}\right)}{\partial x}+\frac{q_{s}}{A} T_{s}$.

Expanding the second term on the right hand side of Eq. (3) by the chain rule, where $A=\pi D^{2} / 4$, results in

$\frac{\partial T_{q}}{\partial t}=\frac{4 h_{t}}{D \rho C_{p}}\left(T_{r}-T_{q}\right)-\frac{4}{\pi D^{2} \rho}\left(\hat{m} \frac{\partial T_{q}}{\partial x}+T_{q} \frac{\partial \hat{m}}{\partial x}\right)+\frac{4 q_{s}}{\pi D^{2}} T_{s}$.

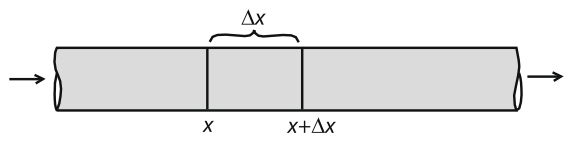

Fig. 1. Conceptual conduit or pipe element.
The change in the mass flow rate in the conduit resulting from diffuse flow entering the conduit is proportional to $q_{s}$ and is expressed as

$\frac{\partial \hat{m}}{\partial x}=q_{s} \rho$.

Velocity $\left(\mathrm{m} \mathrm{s}^{-1}\right)$ in the axial direction is expressed as

$v=\frac{4 \hat{m}}{\pi D^{2} \rho}$.

Substituting Eqs. (5) and (6) into Eq. (4) yields

$\frac{\partial T_{q}}{\partial t}=\frac{4 h_{t}}{D \rho C_{p}}\left(T_{r}-T_{q}\right)-v \frac{\partial T_{q}}{\partial x}-\frac{4 q_{s}}{\pi D^{2}}\left(T_{q}-T_{s}\right)$.

To accommodate diffuse flow entering the conduit, velocity must increase with $x$, and thus $d \hat{m} / d x$ is expressed in terms of $v$ :

$\frac{d \hat{m}}{d x}=\frac{d(\rho A v)}{d x}=\rho\left(\frac{\pi D^{2}}{4}\right) \frac{d v}{d x}$,

which is combined with Eq. (5) and rearranged as

$\frac{d v}{d x}=\frac{4 q_{s}}{\pi D^{2}}$

and then written as

$\Delta v=v_{x}-v_{x=0}=\frac{4 q_{s}\left(x-x_{0}\right)}{\pi D^{2}}$.

Substituting Eq. (10) into Eq. (7) for the case of $x_{0}=0$ yields

$\frac{\partial T_{q}}{\partial t}=\frac{4 h_{t}}{D \rho C_{p}}\left(T_{r}-T_{q}\right)-\left(v_{x=0}+\frac{4 q_{s} x}{\pi D^{2}}\right) \frac{\partial T_{q}}{\partial x}-\frac{4 q_{s}}{\pi D^{2}}\left(T_{q}-T_{s}\right)$,

where $v_{x=0}$ is the axial velocity of water entering the conduit at the upstream end at the point $x=0$.

As described by Eqs. (1)-(11), water in the conduit includes sinking stream water and diffuse flow entering the conduit along its length. In addition to water from the conduit, a well or spring also might receive local diffuse flow that has not interacted with the conduit. For example, a well that is east of the conduit may induce flow from the conduit and also from diffuse flow within the well's zone of influence on the north, south, and east sides of the well (Fig. 2). This local groundwater would be a secondary source of diffuse flow that is not accounted for by Eq. (11) and is assumed to have a constant temperature. Constant temperature is a simplifying assumption and may not be strictly true depending on the flow rate to the well and possible thermal gradients. As the pump-

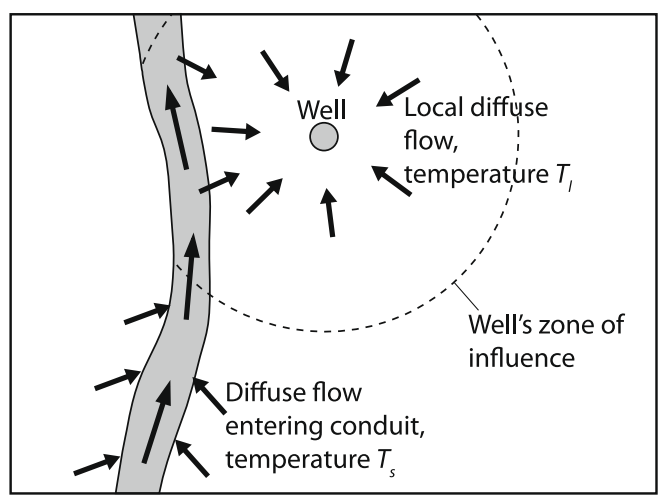

Fig. 2. Map view of conduit and well. Conduit water is a mixture of sinking stream water and diffuse flow that enters the conduit along its length. A nearby well may capture water from the conduit plus local diffuse flow from within the well's zone of influence. 
ing well induces flow from this local groundwater and from water in the conduit of temperature $T_{q}$ (from Eq. (11)), water discharging from the well is then a binary mixture of these two sources. This mixture is represented by

$T_{d}=\alpha T_{q}+(1-\alpha) T_{l}$,

where $T_{d}$ and $T_{l}$ are the temperatures of the mixed water at the discharge point and of local diffuse flow near the well, respectively, and $\alpha$ is the conduit-flow fraction (dimensionless, $0<\alpha<1$ ). Eq. (12) is a simplification and linear approximation of a complex process in a nonlinear system.

The convective heat-transfer coefficient $h_{t}$ can be estimated from equations developed for flow in pipes. First, the dimensionless friction factor $f$ must be estimated either from the Moody diagram (Streeter and Wylie, 1985) or from one of the following equations, which estimate the empirical Moody diagram:

$f=0.0055\left[1+\left(20000 \frac{\varepsilon}{D}+\frac{10^{6}}{R e}\right)^{1 / 3}\right] \quad R e$

$\leqslant 2100$ (de Nevers, 2004),

and

$$
\begin{aligned}
f & =\frac{1.325}{\left[\ln \left(\varepsilon / 3.7 D+5.74 / R e^{0.9}\right)\right]^{2}} \quad 5000 \leqslant R e \\
& \left.\leqslant 10^{8} \quad \text { Streeter and Wylie, } 1985\right),
\end{aligned}
$$

where $\varepsilon$ is the absolute roughness of the pipe (m); Re is the dimensionless Reynolds number $(\operatorname{Re}=D v \rho / \mu)$; and $\mu$ is the kinematic viscosity of water $\left(\mathrm{kg} \mathrm{m}^{-1} \mathrm{~s}^{-1}\right)$. The heat-transfer coefficient $h_{t}$ can be expressed in dimensionless form as a Nusselt number $\left(N u=D h_{t} / k\right)$, which can be estimated for turbulent flow in rough pipes by the following equations from Petukhov (1970):

$h_{t}=\frac{N u \cdot k}{D}=\frac{R e \cdot P r \cdot k}{D \cdot X}\left(\frac{f}{8}\right)$

and

$X=1.07+12.7\left(\operatorname{Pr}^{2 / 3}-1\right)\left(\frac{f}{8}\right)^{1 / 2}$,

where $k$ is the thermal conductivity of water $\left(\mathrm{J} \mathrm{m}^{-1} \mathrm{~s}^{-1} \mathrm{~K}^{-1}\right)$, and $\operatorname{Pr}$ is the dimensionless Prandtl number $\left(\operatorname{Pr}=C_{p} \mu / k\right)$.

Other empirical correlations for estimating $h_{t}$ for fully developed turbulent flow include Colburn (1993), Dittus and Boelter
(1930) and Sieder and Tate (1936). These are only applicable for smooth ducts, and give maximum errors of $\pm 25 \%$ in the range of $0.67<\operatorname{Pr}<100\left(\operatorname{Pr}\right.$ for water at $\left.15^{\circ} \mathrm{C}=8.25\right)$. The Petukhov (1970) equation was chosen because it is applicable for rough ducts by accounting for the effect of roughness on $h_{t}$ and is a more accurate correlation. For $10,000<R e<5000,000$ and $0.5<\operatorname{Pr}<200$, the error associated with the Petukov equation is only $5-6 \%$. The use of Eqs. (13)-(16) assume that the conduit is straight and is a single conduit, which is appropriate for cases where little is known about the geometry of the conduit network. We note that Eqs. (13)(16) were developed empirically for circular pipes, which are much different from the shapes of natural karst conduits. Therefore, these equations provide only a general approximation of $h_{t}$. Also, variation in water viscosity at the conduit wall was neglected and assumed constant.

\section{Model application}

Study area and data collection

The study area is located on the eastern flank of the Black Hills of western South Dakota (Fig. 3). The Mississippian-age Madison Limestone (locally, the Pahasapa Formation) is exposed at the land surface in the western part of the study area at an altitude of about $1300 \mathrm{~m}$ above the National Geodetic Vertical Datum of 1929. Because of uplift and erosion of the Black Hills, the formation is absent to the west of the outcrop and dips below the land surface to the east. The formation is about $130 \mathrm{~m}$ thick in the study area and contains massive fractured and solution-enhanced limestone and dolostone. The Madison aquifer in the study area mainly is contained within the upper part of the Madison Limestone, where extensive karst dissolution has occurred, and generally is unconfined west of $103^{\circ} 18^{\prime}$ west longitude and confined (artesian) to the east (Fig. 3). The Madison aquifer is confined above by the low-permeability units of the lower part of the Minnelusa Formation (Permian and Pennsylvanian age) and confined below by the lower part of the Madison Limestone (Driscoll et al., 2002; Rahn and Gries, 1973) and the underlying Englewood Limestone (Devonian age, $10-20 \mathrm{~m}$ thick). The Minnelusa Formation contains a mixture of sandstone, limestone, and shale layers. Shale layers primarily in the lower part of the Minnelusa Formation form a confining unit, the competency of which is spatially variable. The Englewood Limestone is similar to the lower part of the Madison Limestone in lithology and permeability. The Deadwood aquifer

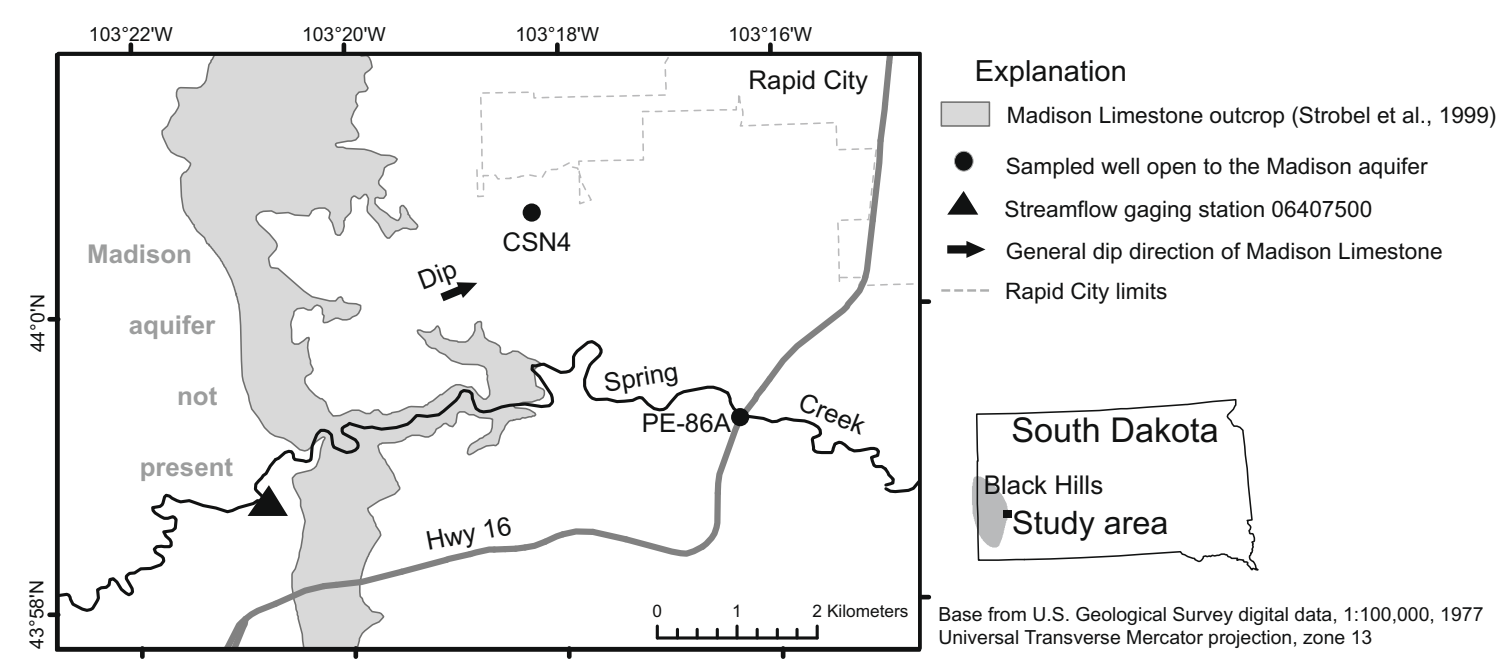

Fig. 3. Study area. (See above-mentioned references for further information.) 
underlies the Englewood Formation and is contained in the sandstones of the Deadwood Formation (Cambrian age).

Recharge to the Madison aquifer in the study area primarily is from Spring Creek, which sinks into the Madison Limestone within the outcrop area (Fig. 3). The catchment area for this watershed is more than $420 \mathrm{~km}^{2}$, and the outcrop area of the Madison Limestone is about $150 \mathrm{~km}^{2}$ in the study area. The Madison aquifer accepts all streamflow in this reach less than or equal to a maximum of about $0.6 \mathrm{~m}^{3} / \mathrm{s}$ (Hortness and Driscoll, 1998). Direct infiltration of precipitation within the outcrop is an additional source of recharge and accounts for less than $10 \%$ of total recharge in the study area (Long and Putnam, 2002). The dominance of the influence of stream recharge in comparison to precipitation recharge is evident in Fig. 4, which shows a large precipitation event beginning on day 142 that was followed by an increase in streamflow. No response in hydraulic head occurred at the time of the precipitation event but
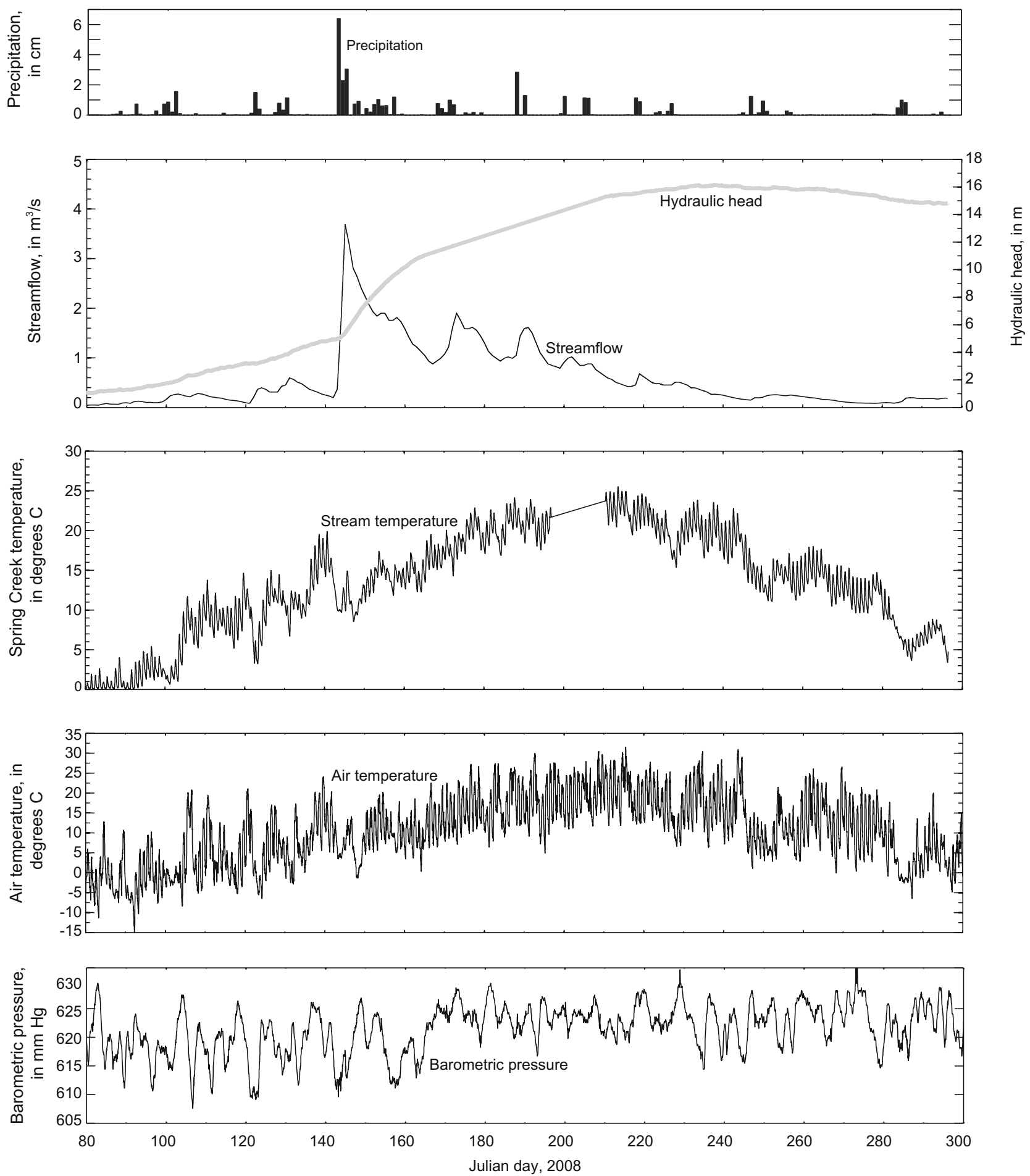

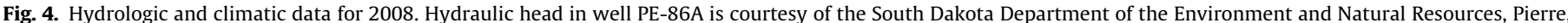

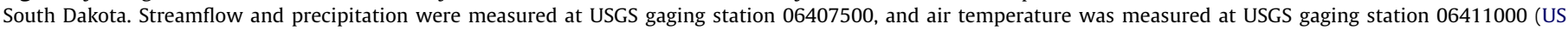
Geological Survey, 2008). Barometric pressure is from the National Oceanic and Atmospheric Administration (2009) for the Custer County Airport. 
rather was concomitant with the increase in streamflow. The slope of hydraulic head for the 5 days before and 5 days after this event was 0.05 and $0.39 \mathrm{~m} / \mathrm{d}$, respectively.

Previous studies indicate a predominant groundwater flow path that originates at the Spring Creek sink and flows north toward Jackson-Cleghorn Springs about $3 \mathrm{~km}$ north of the study area (Greene, 1997; Anderson et al., 1999; Naus et al., 2001; Long and Putnam, 2004), and that this likely is the result of a major karst conduit (Long et al., 2008). A fluorescent dye injection into the Spring Creek sink is consistent with these studies, where tracer velocities to five wells in the study area ranged from about 230 to $1360 \mathrm{~m} / \mathrm{d}$ (Putnam and Long, 2007). Transmissivity values for the Madison aquifer estimated from aquifer tests at wells between 1 and $7 \mathrm{~km}$ north of the study area range from $1100 \mathrm{~m}^{2} / \mathrm{d}$ to $3700 \mathrm{~m}^{2} / \mathrm{d}$ (Greene, 1993; Long and Putnam, 2004).

For 7 months during 2008, water temperature was recorded every $15 \mathrm{~min}$ in Spring Creek and in water pumped from well CSN4 (Fig. 3). This well produces about $230 \mathrm{~m}^{3} / \mathrm{d}$ and probably does not penetrate a conduit directly. The temperature sensor for the creek was the Campbell Scientific, Inc. 107-L, with an accuracy of about $\pm 0.4{ }^{\circ} \mathrm{C}$ in the measurement range, and the sensor for the well was an Omega RTD class A, with an accuracy of \pm 0.03 and $\pm 0.08{ }^{\circ} \mathrm{C}$ at 0 and $100{ }^{\circ} \mathrm{C}$, respectively. The sensor for the well was installed inside the well's water-supply pipe, which emerges from underground inside the well house about $3 \mathrm{~m}$ from the well. The well was pumped almost continuously after Julian day 100 , and temperature measurements during non-pumping periods were removed from the record (Fig. 5). It is noted that this temperature record represents aquifer water that was influenced by pumping and represents all water from within the well's zone of influence.

Well CSN4 is located within the outcrop of the Minnelusa Formation and has an open-hole section (22-cm diameter) from 143-226 m below land surface, which penetrates most of the upper permeable part of the Madison Limestone and part of the lower part (Fig. 6). Steel casing above the open-hole was sealed with concrete grout. The static water level was $132 \mathrm{~m}$ below land surface ( $10 \mathrm{~m}$ below the top of the Madison Limestone) at the time of well construction (July 2002). The temperature in Spring Creek had a clearly diurnal fluctuation of as much as $5{ }^{\circ} \mathrm{C}$ that was in phase with air temperature fluctuations, and an overall range of $0-25{ }^{\circ} \mathrm{C}$ during the simulated period. The temperature of water pumped from well CSN4 decreased from about 14.1 to $13.5^{\circ} \mathrm{C}$ during this period. Between Julian days 104 and 172, the temperature fluctuated as much as $0.4{ }^{\circ} \mathrm{C}$. Before and after this period, temperature in the pumped water generally fluctuated only by about

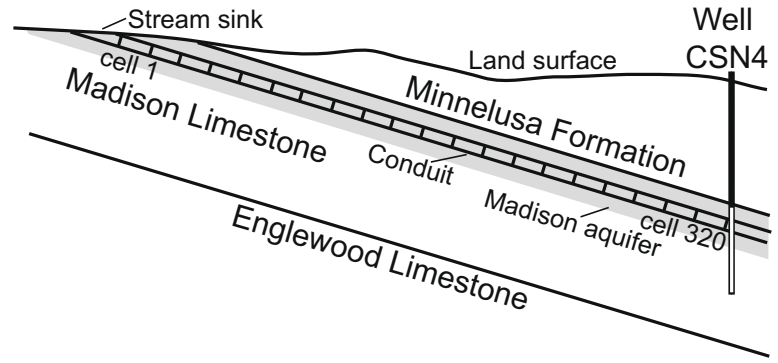

Fig. 6. Hydrogeologic cross-section showing the discretized conduit. The well is some distance from the conduit in the third dimension and thus does not penetrate the conduit directly. The grey shows the upper part of the Madison Limestone, which contains the Madison aquifer. The well casing and open-hole are in black and white, respectively. The conduit is about $3200 \mathrm{~m}$ in length and $140 \mathrm{~m}$ deep at cell 320. Diagram is not to scale.

$0.1^{\circ} \mathrm{C}$, with fluctuations as much as $0.2^{\circ} \mathrm{C}$ after day 240 . Julian days 104-172 were a period of increasing streamflow, which might have been related to the temperature fluctuations in the well.

To better quantify temperature fluctuations, the absolute values of deviations from a 3-day moving average were computed. The standard deviation of these deviations was $5.3 \times 10^{-4}$ for days 104-172 and $2.1 \times 10^{-4}$ for the remaining period.

For the overall measurement period, well temperature cycles that were approximately diurnal were apparent for fluctuations for some periods of about 5 days or less, but between these periods fluctuations appeared to be erratic or too small to detect. Also, fluctuations generally were out of phase with the Spring Creek cycles (and daily air temperature cycles) but occasionally were in phase. This eliminates the possibility that the fluctuations resulted from air temperature effects at the measurement point. Periodicity in the well record may have been masked by overlapping hydrologic effects, but it is uncertain if fluctuations were on a truly diurnal cycle overall.

\section{Model executions and parameter estimation}

Eqs. (11) through (16) were programmed in the commercial math software program MATLAB (http://www.mathworks.com/ products/matlab/). Eq. (11) was solved for $T_{q}(x, t)$ with a finite-difference approximation, whereby the conduit was discretized into 320 pipe elements or cells, each $10 \mathrm{~m}$ in length, and time steps were $15 \mathrm{~min}$. The first cell was at the stream sink, and the last cell was near the well (Fig. 6). Five model parameters were estimated

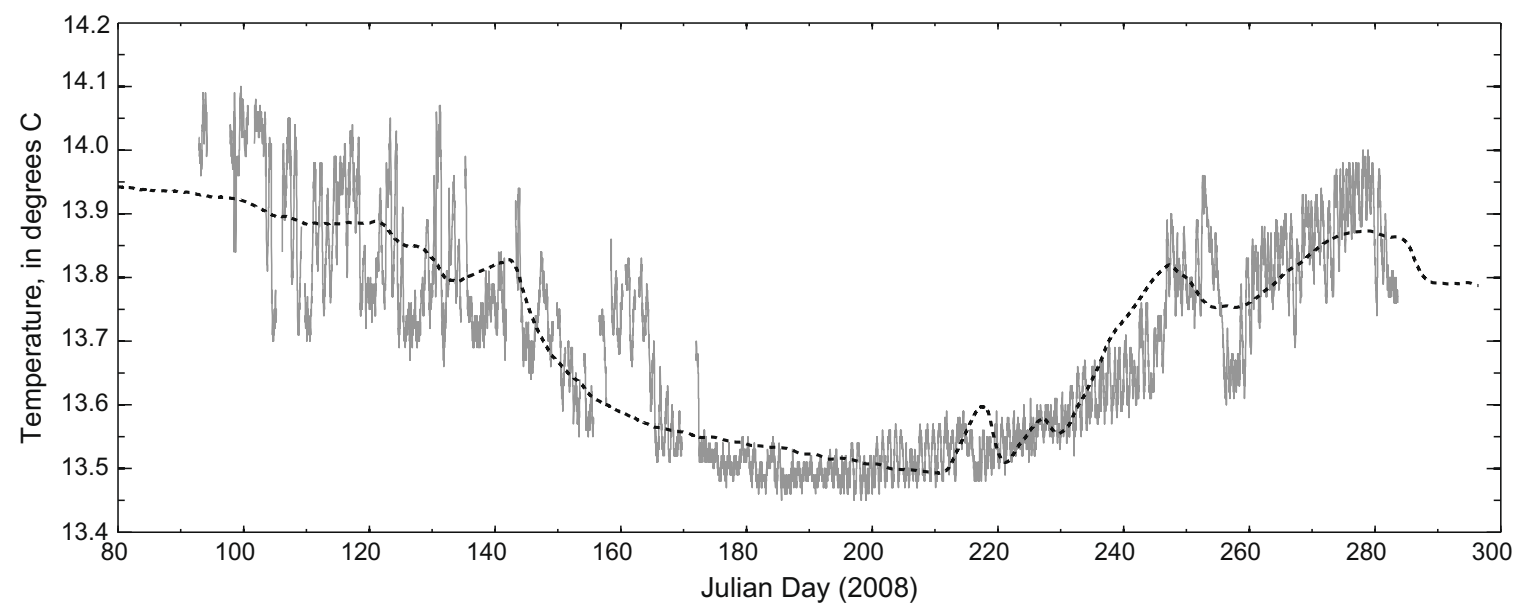

Fig. 5. Measured temperature in well CSN4 (grey), and simulation results (dashed). 
Table 1

Parameter values estimated by inverse modeling.

\begin{tabular}{|c|c|c|c|c|}
\hline Parameter & Best-fit value & Description & Dimensions & Relative parameter sensitivity ${ }^{\mathrm{a}}(\%)$ \\
\hline$T_{s}$ and $T_{r}$ at last cell $(320)$ & 14.0 & Temperature of diffuse flow and of aquifer rocks & ${ }^{\circ} \mathrm{C}$ & 331 \\
\hline$D$ & 2.1 & Conduit diameter & $\mathrm{m}$ & 0.35 \\
\hline$\beta$ & $5.2 \times 10^{-3}$ & Coefficient to weight velocity by hydraulic head & $\mathrm{m}^{-2}$ & 0.02 \\
\hline$\gamma$ & $1.7 \times 10^{-7}$ & Coefficient to weight $q_{s}$ by hydraulic head & $\mathrm{m} \mathrm{s}^{-1}$ & 0.02 \\
\hline$\hat{\alpha}$ & 0.02 & Coefficient to weight conduit flow to the well by hydraulic head & $\mathrm{m}^{-1}$ & 0.17 \\
\hline
\end{tabular}

a The percent change in the sum of the squared residuals resulting from a $1 \%$ change in model parameters as an average of the positive and negative parameter changes.

by inverse modeling (Table 1 ), which was accomplished by the "lsqcurefit" function in MATLAB to minimized the differences, or residuals, between simulated and observed temperature values. This is a subspace trust-region method and is based on the interior-reflective Newton method (Coleman and Li, 1994, 1996).

Velocity was weighted by the rate of sinking streamflow, where velocity at the conduit inflow point was computed as the constant $\beta\left[\mathrm{m}^{-2}\right]$ times the sink rate, where $\beta$ was estimated by inverse modeling.

The temperature of the aquifer rocks including the conduit wall increases with depth because of the geothermal gradient. Therefore, it was assumed that the inlet end of the conduit is at the stream sink, the downgradient end is within the Madison aquifer, and the intervening depths and temperatures change linearly according to the geothermal gradient (Fig. 6). At the depth of the well's open interval, the temperature of diffuse flow probably was about $14^{\circ} \mathrm{C}$ because this was the well temperature at the beginning of the record, which would have mainly represented local diffuse flow because streamflow was low at that time (Fig. 4, Julian days 92-104). Temperature of diffuse flow was assumed to equal that of the aquifer rocks $\left(T_{s}=T_{r}\right)$. This assumption was made because at very low groundwater velocities equilibrium would be reached. However this is a simplification of the system because slow flow might travel at different velocities at which equilibrium might not be reached. Parameters $T_{s}$ and $T_{r}$ at the stream sink (cell 1) were set equal to the average air temperature for the area ( $4.4^{\circ} \mathrm{C}$, Natural Resources Conservation Service 2009; North Rapid Creek station) and were estimated by inverse modeling at the conduit depth near the well (cell 320). For each cell these parameters were assumed constant in time. Temperature fluctuations at the conduit inlet are equal to those of the stream but decrease in a downstream direction due to heat exchange between water and rock (Benderitter et al., 1993) and also from diffuse flow entering along the length of the conduit.

A plausible range of $T_{s}$ and $T_{r}$ at cell 320 was determined based on a possible range of conduit depths, geothermal gradients, and the water temperature within Wind Cave, about $50 \mathrm{~km}$ south of the study area. This cave is in the Madison Limestone and contains a slow-flowing water body with a temperature of $13.8 \pm 0.05^{\circ} \mathrm{C}$ at a depth of $138 \mathrm{~m}$ below land surface (Wind Cave National Park data archives). The top of the Madison Limestone in the study area near the well is $122 \mathrm{~m}$ deep, and if we assume that the conduit is contained within the upper one-third of the formation, then its depth could range from 122 to $165 \mathrm{~m}$. The geothermal gradient, which generally ranges from 10 to $30^{\circ} \mathrm{C} / \mathrm{km}$ (Judson et al., 1976), was used to estimate a plausible range for $T_{s}$ and $T_{r}$ at cell 320 based on the water temperature in the cave. We assumed that $T_{S}$ and $T_{r}$ were $13.8^{\circ} \mathrm{C}$ at a depth of $138 \mathrm{~m}$ and then computed $T_{s}$ and $T_{r}$ at depths of 122 and $165 \mathrm{~m}$ using the larger end point of the geothermal gradient range $\left(30^{\circ} \mathrm{C} / \mathrm{km}\right)$. On this basis, the largest plausible temperature range should be $13.3-14.6^{\circ} \mathrm{C}$. Inverse modeling was used to estimate $T_{s}$ and $T_{r}$ at cell 320 , the value of which was compared to this range.

Diffuse flow entering along the length of the conduit $q_{s}$ was assumed to decrease as conduit recharge from streamflow increased because of increasing conduit fluid pressure. Mahler and Massei (2007) concluded that increases in hydraulic head resulted in an increased quick-flow fraction in a karst aquifer. Because of the dominance of stream recharge in the study area, groundwater flows from the conduit into the surrounding aquifer during wet periods when streamflow is high and then drains back into the conduit during low-flow periods (Long and Putnam, 2004). Hydraulic head was thus used as an indication of increasing conduit fluid pressure resulting from conduit recharge from streamflow, and $q_{s}$ was weighted inversely by hydraulic head in well PE-86A (Figs. 3 and 4). This was done by computing the difference between the highest hydraulic head for 2008 and the measured hydraulic head and multiplying this difference by the constant $\gamma$ $\left[\mathrm{m} \mathrm{s}^{-1}\right]$, which was estimated by inverse modeling. $q_{s}$ is never negative because during wet periods when streamflow is greater than the maximum sink rate and groundwater flows from the conduit to the surrounding aquifer, any loss of flow in the conduit is assumed to be compensated for by an increase in the sink rate, and velocity in the conduit would reach and equilibrium.

The conduit-flow fraction entering the well $\alpha$ (Eq. (12)) was weighted by hydraulic head and was computed as the constant $\hat{\alpha}$ $\left[\mathrm{m}^{-1}\right]$ times hydraulic head, where $\hat{\alpha}$ was estimated by inverse modeling. A karst conduit was assumed to have much greater roughness than a uniform concrete pipe, and thus a value of $0.03 \mathrm{~m}$ was used as the absolute roughness, which is one order of magnitude larger than that of rough concrete (Streeter and Wylie, 1985). Conduit diameter $D$ was estimated by inverse modeling.

\section{Preliminary model executions using synthetic data}

To test the model and to help illustrate the effects of hydraulic head, stream temperature, and conduit inflow velocity, and to provide insight into model interpretation, the model was initially executed under a series of synthetic data records for these inputs. Constant values, linear functions, and sine waves were used in different combinations for these model inputs. Fig. 7 shows the simulated well temperatures (the point of discharge) under these different scenarios. Input records with changing values are shown, and if not shown, inputs were set at constant values. Fig. 7a and b shows that the simulated well temperature is inversely proportional to hydraulic head. When hydraulic head is zero, diffuse flow dominates and the simulated well temperature is about $14^{\circ} \mathrm{C}$, which is the temperature of $T_{s}$ in cell 320 (Fig. 7a). As hydraulic head increases diffuse flow decreases, and the simulated well temperature also decreases to about $13.5^{\circ} \mathrm{C}$. This decrease results from the increasing influence of conduit water in contact with upgradient rocks at temperatures cooler than $14^{\circ} \mathrm{C}$. Thus simulated well temperature is inversely proportional to hydraulic head. Fig. 7b shows the simulated well temperature oscillating between about 13.5 and $14.0^{\circ} \mathrm{C}$, which responds inversely to oscillating hydraulic head.

Fig. 7c shows that the simulated well temperature was relatively insensitive to changes in stream temperature because these input temperature changes were damped by contact with the conduit walls and the influence of diffuse flow. Thus this 

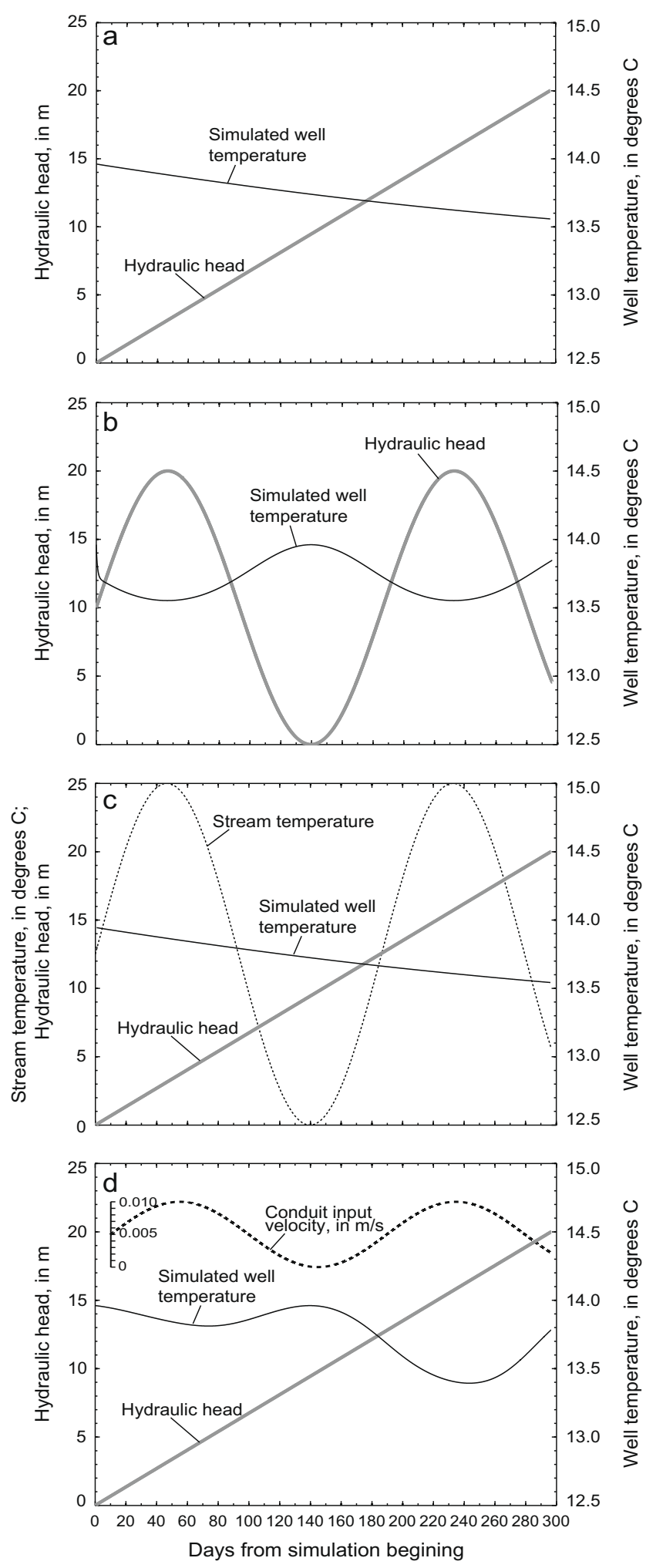

Fig. 7. Simulated well temperature using synthetic data as model inputs under four different scenarios: (a) hydraulic head increases linearly, (b) hydraulic head is a sine wave, (c) stream temperature is a sine wave and hydraulic head increases linearly, and (d) conduit input velocity is a sine wave and hydraulic head increases linearly. Where unspecified, stream temperature and conduit input velocity were constant at $20^{\circ} \mathrm{C}$ and $0.005 \mathrm{~m} / \mathrm{s}$, respectively. For all executions $T_{s}$ and $T_{r}$ in cell 320 were constant at $14^{\circ} \mathrm{C}$. Parameters $D, \beta, \gamma$, and $\hat{\alpha}$ were constant at $2.0,1.0,1 \times 10^{-7}$, and 0.02 , respectively.

simulated well temperature was almost identical to that of Fig. 7a, where stream temperature was constant. Fig. 7d shows the combined influences of linearly increasing hydraulic head and oscillating inflow velocity, where the simulated well temperature is inversely proportional to inflow conduit velocity. The simulated conduit temperature in cell 320 was influenced by the temperatures of aquifer rocks upgradient in the conduit, which had a median temperature of $9^{\circ} \mathrm{C}$, as well as the rock temperature at cell $320\left(14^{\circ} \mathrm{C}\right)$. The contact time between conduit water and rock, which is a function of velocity, influences conduit water temperatures. For any particular conduit cell, low velocities give more weight the rock temperature of that cell, whereas high velocities give more weight to rock temperatures of upgradient cells. Thus there is an inverse relation between conduit velocity and temperature. This effect is more pronounced when hydraulic head is high because of the combined effects.

\section{Final results}

The final results of the full geologic example using inverse modeling to best match the measured temperature record for the well are shown in Fig. 5. There is an apparent inverse relation between stream temperature and well temperature. However, as previously described by the preliminary model executions, simulated well temperature is relatively insensitive to stream temperature. The decrease in well temperature between days 150 and 240 resulted from the combined effects of hydraulic head and conduit inflow velocity because there is an inverse relation between well temperature and both of these inputs.

The simulated temperature results matched the overall change in temperature in the well over the measurement period in general but did not match the short-term fluctuations that occurred from days 104 to 172 . These fluctuations apparently were the result of phenomena that are not understood and are not accounted for by the model. The simulated heat-transfer between the conduit wall and conduit water and the inflow of diffuse flow $q_{s}$ resulted in heavy damping of the input signal (Spring Creek temperature) in the simulated well response. The smaller fluctuations in the well response before day 104 and after day 172 indicate that model assumptions were reasonable for these periods but that an additional process occurred during the intervening period. This possibly resulted from changing springtime conditions, such as increasing streamflow and hydraulic head, which roughly coincided with a general decrease in the well temperature from about 14.1 to $13.5^{\circ} \mathrm{C}$. The simulated temperature in the last cell of the conduit had a larger range $\left(11.8-13.7^{\circ} \mathrm{C}\right)$ than that of the well because of the influence of diffuse flow entering the well. Parameters estimated by inverse modeling are shown in Table 1, and parameters that were calculated from those in Table 1 or by other means are shown in Table 2.

The estimated value of $T_{s}$ and $T_{r}$ for cell $320\left(14.0^{\circ} \mathrm{C}\right)$ was about the mid-point of the plausible range $\left(13.3\right.$ to $\left.14.6{ }^{\circ} \mathrm{C}\right)$. The total inflow rate at the conduit inlet ranged from 0 to $0.0084 \mathrm{~m}^{3} / \mathrm{s}$ for the simulation period. Simulated values of $q_{s}$ equated to a total inflow rate from the surrounding aquifer ( $q_{s}$ times conduit length) in the range of $0-0.0084 \mathrm{~m}^{3} / \mathrm{s}$. The conduit-flow fraction $\alpha$ ranged from $2 \%$ to $31 \%$ of total flow. Simulated conduit velocity (as an average of all cells in the conduit) ranged from 44 to $353 \mathrm{~m} / \mathrm{d}$, which is consistent with the dye velocity of $315 \mathrm{~m} / \mathrm{d}$ for this well in 2004 (Putnam and Long, 2007).

The sum of the squared residuals (ssr) was equal to 93.9. The ssr was used to assess parameter sensitivity by changing the value of each parameter by $1 \%$ and observing the resulting percent change in the ssr (Table 1). The model was by far most sensitive to $T_{s}$ and $T_{r}$ for cell 320 . The parameter $D$ was the next most sensitive parameter followed by $\hat{\alpha}, \beta$, and $\gamma$. 
Table 2

Parameter values determined from model results or assumed.

\begin{tabular}{|c|c|c|c|c|}
\hline Parameter & $\begin{array}{l}\text { Calculated value } \\
\text { or range over time }\end{array}$ & Description & Determined by & Dimensions \\
\hline$q_{s}$ & $0-2.5 \times 10^{-6}$ & $\begin{array}{l}\text { Flow rate per unit length of conduit } \\
\text { of diffuse flow entering conduit }\end{array}$ & $\begin{array}{l}\text { Range over simulated period from model } \\
\text { results (Eq. (11)) }\end{array}$ & $\mathrm{m}^{3} \mathrm{~s}^{-1} \mathrm{~m}^{-1}$ \\
\hline$\alpha$ & $0.02-0.31$ & Conduit-flow fraction & $\begin{array}{l}\text { Range over simulated period from model } \\
\text { results (Eq. (12)) }\end{array}$ & Dimensionless \\
\hline$h_{t}$ & 12.1 & $\begin{array}{l}\text { Convective heat-transfer coefficient } \\
\text { between the conduit water } \\
\text { and conduit wall }\end{array}$ & $\begin{array}{l}\text { Constant value from model results (Eqs. } \\
(13)-(16) \text { ) }\end{array}$ & $\mathrm{J} \mathrm{s}^{-1} \mathrm{~m}^{-2} \mathrm{~K}^{-1}$ \\
\hline$f$ & 0.052 & Friction factor & $\begin{array}{l}\text { Constant value from model results (Eqs. } \\
(13)-(16) \text { ) }\end{array}$ & Dimensionless \\
\hline Re & $3.3 \times 10^{3}$ & Reynolds number & $\begin{array}{l}\text { Constant value from model results (Eqs. } \\
(13)-(16) \text { ) }\end{array}$ & Dimensionless \\
\hline $\operatorname{Pr}$ & 9.1 & Prandtl number & $\begin{array}{l}\text { Constant value from model results (Eqs. } \\
(13)-(16) \text { ) }\end{array}$ & Dimensionless \\
\hline$\varepsilon$ & 0.03 & Absolute roughness & Value of rough concrete $\times 10$ (assumed) & $\mathrm{m}$ \\
\hline
\end{tabular}

These parameters were not estimated by inverse modeling.

\section{Discussion}

In the simulation, damping of the input temperature record (Spring Creek) in the conduit resulted from heat exchange between rocks and water in the conduit, and this damping increased in a downgradient direction (Fig. 8). The temperature record in cell 40 is similar to that of Spring Creek, except downscaled. As the cell number increases (downgradient), the temperature record is progressively damped, or flattened. At the last cell (320) the general character of the temperature record is heavily damped but generally inverse to the Spring Creek record; i.e., there is a decrease in conduit water temperature when the creek temperature is rising. However, this apparent inverse relation is merely coincidental; rather, the decrease in conduit water temperature resulted from an increase in conduit velocity as previously described (Fig. 7d).

The decrease in well temperature (Fig. 5) results partially from the coinciding decrease in conduit water temperature in cell 320 (Fig. 8) and partially from an increase in the ratio of conduit flow at about $12{ }^{\circ} \mathrm{C}$ in cell 320 to local diffuse flow at $14{ }^{\circ} \mathrm{C}$.

The simulated total inflow rate at the conduit inlet $(0-$ $0.0084 \mathrm{~m}^{3} / \mathrm{s}$ ) is a small fraction of the maximum stream sink rate of $0.6 \mathrm{~m}^{3} / \mathrm{s}$. The reason for this may be that the stream flows into multiple passages that compose a conduit system, which has the

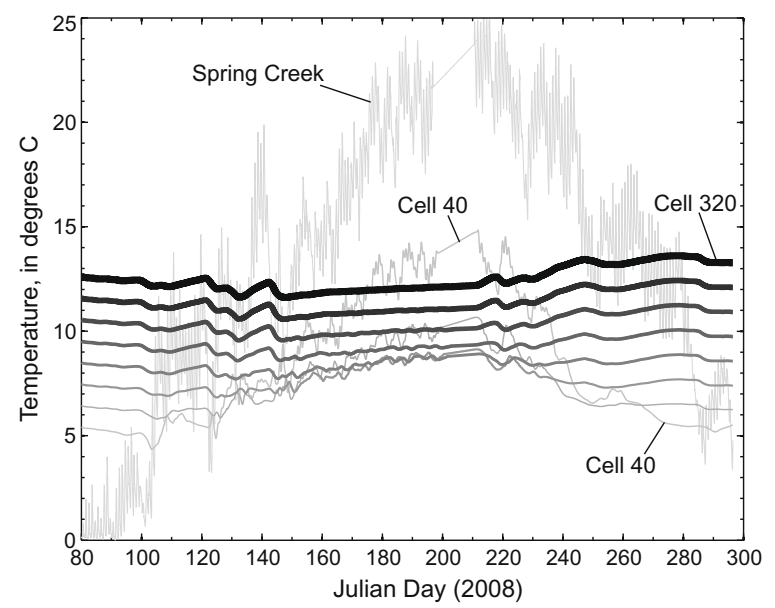

Fig. 8. Conduit temperature propagation along the length of the conduit. The temperature in Spring Creek was the input temperature into cell 1. The temperature for every fortieth cell is shown from cell 40 through cell 320 with increasing line weight. The plot shows the effects of temperature damping in a downgradient direction. capacity to accept the full amount of sinking stream water. The model then is assumed to have simulated a particular passage that carries a fraction of the total conduit flow and is within the well's zone of influence, but not penetrated by the well. This interpretation is consistent with the 2004 dye trace (Putnam and Long, 2007), which indicated that the dye concentration and transit time was much less for well CSN4 than for four other wells that also responded to dye injections in the Spring Creek sink. Well CSN4 is to the west of these other wells that may be in the path of larger conduits. Groundwater velocities to the five wells determined from this dye trace ranged from about 230 to $1360 \mathrm{~m} / \mathrm{d}$, and peak concentrations ranged from about 1 to $34 \mu \mathrm{g} / \mathrm{L}$. Velocity and concentration for well CSN4 were near the lower end of these ranges ( $315 \mathrm{~m} / \mathrm{d}$ and $1 \mu \mathrm{g} / \mathrm{L}$, respectively).

Other evidence for branching of conduits from the Spring Creek sink include work by Long and Putnam (2004), where stable isotopes in the creek showed a response in the Madison aquifer that was partially attributed to anastomosis of conduits. A spatial analysis of environmental tracers in the Madison aquifer indicated a conduit extending from the Spring Creek sink that bifurcates to the north and east (Long et al., 2008). Branching of cave passages is common in the Madison Limestone in the Black Hills as shown by intricate passage networks in several caves (Greene and Rahn, 1995; Horrocks and Szukalski, 2002).

The inability of the model to simulate short-term fluctuations during spring and early summer may be its major limitation. These fluctuations probably did not result from Spring Creek temperature fluctuations because the frequencies were not consistently in or out of phase with Spring Creek, and further, the largest fluctuation resulted when Spring Creek was flowing the least. The model executions using synthetic data indicate that the system is heavily damped resulting in the insensitivity of the model to short-term temperature changes in Spring Creek. Pumping of the well does not explain this phenomenon either because the pumping rate was relatively constant. Without more knowledge of the complex processes that account for these well fluctuations, it is not possible for this model to accurately simulate them. However, the model may be helpful in making inferences about these processes. For example, we can be relatively confident that these short-term fluctuations do not result directly from diurnal fluctuations in Spring Creek temperatures, which might be assumed otherwise. While the model accounts for the general seasonal changes in well temperatures resulting from the major system processes, short-term fluctuations may be the result of additional factors that have yet to be determined. One such factor might be rapid changes in the ratio of conduit flow to local diffuse flow, possibly as a result of fac- 
tors such as barometric pressure changes for example. In any case, the elimination of some possible causes may help to facilitate the determination of actual causes and thus is one useful outcome of this study.

The largest short-term fluctuations occurred during a temperature transition period from days 104 to 172 when the well temperature was decreasing from a temperature close to that of diffuse flow $\left(14^{\circ} \mathrm{C}\right)$ to a temperature closer to that of conduit flow. Simulation results indicate that during this transition period the well increased from less than $5 \%$ to more than $25 \%$ conduit flow, which partially resulted in the overall decrease in well temperature. Because the diurnal fluctuations in the simulated conduit temperatures were damped by heat-transfer with the conduit walls, the well fluctuations probably were the result of rapidly changing mixtures of the two waters, but the processes that influence these rapid changes are not understood.

In terms relevant to assessing contaminant vulnerability to a sinking stream, the model is useful for making general estimates of the conduit-flow fraction. Simulation results indicate that the well is susceptible to the quick transport of stream contamination during high-flow periods.

\section{Conclusions}

A one-dimensional heat-transport model was developed for simulating temperature responses in wells or springs open to or flowing from karst aquifers composed of conduits and diffuse fissured systems. The model was based on an energy balance for a cylindrical conduit element that allows inflow of diffuse flow through fissures or other small openings. Additional diffuse flow within the zone of influence of the well or spring that has not interacted with the conduit was accounted for with a binary mixing equation to proportion this flow relative to conduit flow. This model is useful for estimating the conduit-flow fraction to a well or spring and thus is helpful in assessing contaminant vulnerability.

The model was applied to measured temperature in a well open to the Madison aquifer in the Black Hills of western South Dakota, where a sinking stream flows into a conduit system and provides a large majority of recharge to the aquifer in the study area. The well is near a conduit and contains water from the conduit and local diffuse flow from outside of the conduit. The simulated conduit was discretized into 320 finite-difference conduit elements to approximate the solution, where the inflow end was at the sinking stream, and the downstream end was near the well.

Inverse modeling was applied to estimate model parameters. The simulated conduit-flow fraction to the well ranged from $2 \%$ to $31 \%$ of the total. The temperature of the diffuse flow and aquifer rocks (assumed equal) at the depth of the conduit near the well was $14.0^{\circ} \mathrm{C}$, the conduit diameter was $2.1 \mathrm{~m}$, and the simulated conduit velocity ranged from 44 to $353 \mathrm{~m} / \mathrm{d}$ over the simulation period, which is within the range determined from previous dye tracing. The simulation results matched the general decrease in well temperature but did not match the short-term temperature fluctuations that occurred during a transition period, where the well temperature decreased from the temperature of diffuse flow to the temperature of conduit flow. This occurred during a period of increasing streamflow, which resulted in increased conduit flow. These short-term fluctuations probably resulted from rapidly changing mixtures of conduit flow and diffuse flow that occurred during a period of changing hydrologic conditions. Diurnal temperature fluctuations in the sinking stream were not evident in the measured well temperatures. These fluctuations likewise were heavily damped in the simulation and thus were not present in the simulated conduit flow or well temperatures.

\section{Acknowledgements}

This study was done in cooperation with the West Dakota Water Development District and the city of Rapid City, South Dakota. The authors thank the Country Side Subdivision and Bob Powles for assistance with temperature monitoring. Any use of trade, product, or firm names is for descriptive purposes only and does not imply endorsement by the US Government.

\section{References}

Anderson, M.P., 2005. Heat as a ground water tracer. Ground Water 43 (6), 951-968. Anderson, M.T., Driscoll, D.G., Williamson, J.E., 1999. Ground-Water and SurfaceWater Interactions along Rapid Creek Near Rapid City, South Dakota, US Geological Survey Water-Resources Investigation Report 98-4214. <http:// pubs.er.usgs.gov/usgspubs/wri/wri984214>.

Andre, B.J., Rajaram, H., 2005. Dissolution of limestone fractures by cooling waters: Early development of hypogene karst systems. Water Resources Research 41 (1), 1-16.

Aravinth, S., 2000. Prediction of heat and mass transfer for full developed turbulent fluid flow through tubes. International Journal of Heat and Mass Transfer 43, 1399-1408.

Beek, W.J., Muttzall, M.K., van Heuven, J.W., 1999. Transport Phenomena, second ed. John Wiley \& Sons Ltd., West Sussex, England. 329 p.

Benderitter, Y., Roy, B., Tabbagh, A., 1993. Flow characterization through heat transfer evidence in a carbonate fractured medium: first approach. Water Resources Research 29 (11), 3741-3747.

Benim, A.C., Cagan, M., Gunes, D., 2004. Computation analysis of transient heat transfer in turbulent pipe flow. International Journal of Thermal Sciences 43 , 725-732.

Birk, S., 2002. Characterization of Karst Systems by Simulating Aquifer Genesis and Spring Responses: Model Development and Application to Gypsum Karst. Tübinger Geowissenschaftliche Arbeiten, vol. 60. Reihe C. Institut und Museum für Geologie und Paläontologie der Universität Tübingen, Tübingen, Germany. <http://w210.ub.uni-tuebingen.de/dbt/volltexte/2002/558/>.

Birk, S., Liedl, R., Sauter, M., 2006. Karst spring responses examined by processbased modeling. Ground Water 44 (6), 832-836.

Bogan, T., Mohseni, O., Stefan, H.G., 2003. Stream temperature-equilibrium temperature relationship. Water Resources Research 39 (9), 1245 doi:10.1029/2003WR002034.

Bredehoeft, J.D., Papadopulos, I.S., 1965. Rates of vertical groundwater movement estimated from the earth's thermal profile. Water Resources Research 1 (2), 325-328.

Colburn, A.P., 1933. A method of correlating forced convection heat transfer data and a comparison with liquid frictions. Transactions of the American Institute of Chemical Engineers 29, 174-210.

Coleman, T.F., Li, Y., 1994. On the convergence of reflective newton methods for large-scale nonlinear minimization subject to bounds. Mathematical Programming 67 (2), 189-224.

Coleman, T.F., Li, Y., 1996. An interior, trust region approach for nonlinear minimization subject to bounds. SIAM Journal on Optimization 6, 418-445.

de Nevers, N., 2004. Fluid Mechanics for Chemical Engineers, third ed. McGraw-Hill, New York. $656 \mathrm{p}$

Dittus, F.W., Boelter, L.M.K., 1930. Heat Transfer in Turbulent Pipe and Channel Flow. Publications on Engineering, vol. 2. University of California, Berkeley. pp. 443-461.

Dogwiler, T., Wicks, C.M., Jenzen, E., 2007. An assessment of the applicability of the heat pulse method toward the determination of infiltration rates in karst losingstream reaches. Journal of Cave and Karst Studies 69 (2), 237-242.

Driscoll, D.G., Carter, J.M., Williamson, J.E., Putnam, L.D., 2002. Hydrology of the Black Hills Area, South Dakota. US Geological Survey Water-Resources Investigations Report 02-4094. <http://pubs.er.usgs.gov/usgspubs/wri/ wri024094>.

Edinger, J.E., Duttweiler, D.W., Geyer, J.C., 1968. The response of water temperatures to meteorological conditions. Water Resources Research 4 (5), 1137-1143.

Genthon, P., Bataille, A., Fromant, A., D'Hulst, D., Bourges, F., 2005. Temperature as a marker for karstic waters hydrodynamics. Inferences from 1 year recording at la Peyrére cave (Ariège, France). Journal of Hydrology 311 (1-4), 157-171.

Gnielinski, V., 1976. New equations for heat and mass transfer in turbulent pipe and channel flow. International Chemical Engineering 16 (2), 359-368.

Greene, E.A., 1993. Hydraulic Properties if the Madison Aquifer System in the Western Rapid City Area, South Dakota. US Geological Survey Water-Resources Investigations Report 93-4008. <http://pubs.er.usgs.gov/usgspubs/wri/ wri934008>

Greene, E.A., 1997. Tracing recharge from sinking streams over spatial dimensions of kilometers in a karst aquifer. Ground Water 35 (5), 898-904.

Greene, E.A., Rahn, P.H., 1995. Localized anisotropic transmissivity in a karst aquifer. Ground Water 33 (5), 806-816.

Healy, R.W., Ronan, A.D., 1996. Documentation of Computer Program VS2Dh for Simulation of Energy Transport in Variably Saturated Porous Media; Modification of the US Geological Survey's Computer Program VS2DT. US Geological Survey Water-Resources Investigations Report 96-4230. <http:// pubs.er.usgs.gov/usgspubs/wri/wri964230>. 
Horrocks, R.D., Szukalski, B.W., 2002. Using geographic information systems to develop a cave potential map for Wind Cave, South Dakota. Journal of Cave and Karst Studies 64 (1), 63-70.

Hortness, J.E., Driscoll, D.G., 1998. Streamflow Losses in the Black Hills of Western South Dakota: US Geological Survey Water-Resources Investigations Report 984116. <http://pubs.er.usgs.gov/usgspubs/wri/wri984116>.

Judson, S., Deffeyes, K.S., Hargraves, R.B., 1976. Physical Geology. Prentice-Hall, Inc. Englewood Cliffs, NJ. 560 p.

Liedl, R., Sauter, M., 2000. Characterization of karst groundwater processes, using models of aquifer genesis and heat transport. Grundwasser 5 (1), 9-16.

Long, A.J., Putnam, L.D., 2002. Flow-System Analysis of the Madison and Minnelusa Aquifers in the Rapid City Area, South Dakota - Conceptual Model. US Geological Survey Water-Resources Investigations Report 02-4185. <http:// pubs.er.usgs.gov/usgspubs/wri/wri024185>.

Long, A.J., Putnam, L.D., 2004. Linear model describing three components of flow in karst aquifers using ${ }^{18} \mathrm{O}$ data. Journal of Hydrology 296, 254-270.

Long, A.J., Sawyer, J.F., Putnam, L.D., 2008. Environmental tracers as indicators of karst conduits in ground water in South Dakota, USA. Hydrogeology Journal 16 (2), 263-280.

Lu, N., Ge, S., 1996. Effect of horizontal heat and fluid flow on the vertical temperature distribution in a semi confining layer. Water Resources Research 32 (5), 1449-1453.

Mahler, B.J., Massei, N., 2007. Anthropogenic contaminants as tracers in an urbanizing karst aquifer. Journal of Contaminant Hydrology 91 (1-2), 81-106.

Natural Resources Conservation Service, 2009. Digital Data. <http:// www.wcc.nrcs.usda.gov/snow/snotel-temp-data.html> (accessed 4.7.2008)

National Oceanic and Atmospheric Administration, 2009. National Climatic Data Center, Digital Data. <http://www.ncdc.noaa.gov/oa/ncdc.html> (accessed 6.7.2009).

Naus, C.A., Driscoll, D.G., Carter, J.M., 2001. Geochemistry of the Madison and Minnelusa Aquifers in the Black Hills Area, South Dakota. US Geological Survey Water-Resources Investigations Report 01-4129. <http://pubs.er.usgs.gov/ usgspubs/wri/wri014129>.
O’Driscoll, M.A., DeWalle, D.R., 2006. Stream-air temperature relations to classify stream-ground water interactions in a karst setting, central Pennsylvania, USA Journal of Hydrology 329 (1-2), 140-153.

Petukhov, B.S., 1970. Heat transfer and friction in turbulent pipe flow with variable physical properties. In: Hartnett, J.P., Irvine, T.F. (Eds.), Advances in Heat Transfer. Academic Press, New York, pp. 504-564.

Putnam, L.D., Long, A.J., 2007. Analysis of Ground-Water Flow in the Madison Aquifer using Fluorescent Dyes Injected in Spring Creek and Rapid Creek Near Rapid City, South Dakota, 2003-2004. US Geological Survey Scientific Investigations Report 2007-5137. <http://pubs.er.usgs.gov/usgspubs/sir/ sir20075137>.

Rahn, P.H. Gries, J.P. 1973. Large Springs in the Black Hills, South Dakota and Wyoming. Report of Investigations 107 - Department of Natural Resource Development, South Dakota Geological Survey, 100 p.

Shoemaker, W.B., Sumner, D.M., Castillo, A., 2005. Estimating changes in heat energy stored within a column of wetland surface water and factors controlling their importance in the surface energy budget. Water Resources Research 41, W10411. doi:10.1029/2005WR004037.

Sieder, E.N., Tate, G.E., 1936. Heat transfer and pressure drop of liquids in tubes. Industrial \& Engineering Chemistry 28, 1429-1435.

Streeter, V.L., Wylie, E.B., 1985. Fluid Mechanics. McGraw-Hill, Inc.. 586 p.

Strobel, M.L., Jarrell, G.J., Sawyer, J.F., Schleicher, J.R., Fahrenbach, M.D., 1999. Distribution of hydrogeologic units in the Black Hills Area, South Dakota. US Geological Survey Hydrologic Investigations Atlas HA-0743. <http:// pubs.er.usgs.gov/usgspubs/ha/ha743>.

US Geological Survey, 2008. National Water Information System, Digital Data <http://waterdata.usgs.gov/sd/nwis/> (accessed 31.7.2008).

Voss, C.I., Provost, A.M., 2002. SUTRA: A Model for 2D or 3D Saturated-Unsaturated, Variable-Density Ground-Water Flow with Solute or Energy Transport. US Geological Survey Water-Resources Investigations Report 02-4231. <http:// pubs.er.usgs.gov/usgspubs/wri/wri024231>. 